\title{
ІНСТИТУЦІЙНІ ЗАСАДИ РОЗВИТКУ ПІДПРИЄМНИЦТВА В АГРАРНІЙ СФЕРІ
}

\author{
Сухоставець Андрій Іванович \\ кандидат економічних наук, доцент \\ Сумський національний аграрний університет (м.Суми, Україна) \\ ORCID: 0000-0002-4101-4105 \\ 9264374@gmail.com
}

В статті проведений є аналіз ситуації з формуванням підприємництва, його інституційного середовища, розроблені шляхи покращення інституційного середовища розвитку підприємництва в аграрній сфері.

В статті доведено, що основними формами державної підтримки підприємництва в агарній сфрері є: політична, економічна, соціальна, екологічна. В статті аргументовано, що підтримка розвитку підприємництва повинна базуватися на сприятливому інституційному середовищі, визначено що стимулюючим фрактором розвитку підприємницької діяльності є удосконалення нормативної бази та реорганізація органів управління, що призведе до покращення інституційного середовища та в свою чергу стане потужним інструментом для активізації підприємницької діяльності і буде сприяти сталому економічному розвитку держави.

Нами визначено, що в подальшому свої дослідження з даного питання будуть направлені на розробку дієвих механізмів створення сприятливих умов для розвитку підприємництва в агарній сфері як з боку держави так і збоку іноземних донорів в частині технічної, інформаційної та навчальної підтримки.

Ключові слова: підприємництво, інституції, інституційні засади, сільськогосподарське виробництво.

DOI: https://doi.org/10.32845/bsnau.2019.2.7

Постановка проблеми в загальному вигляді. Розвиток бізнесу, а особливо в аграрному секторі Україні відбувається в умовах постійного реформування, зміни законодавства України соціально-економічного та політичного середовища, суспільної думки. Підприємства постійно стикаються 3 різними проблемами, особливо фінансовими, економічними, майновими, нестачі висококваліфікованих кадрів та іншими.

Для кожної держави одним з основних пріоритетів $€$ розвиток підприємництва в аграрній сфері, де виробляється продукція, надаються послуги, завдяки якому розвивається сільська територія та регіон в цілому.

Зміст підприємництва, як основи діяльності визначено в Конституції як право громадян на підприємницьку діяльність. Відповідно до статті 42 Конституції України (Конституція України, 1996) кожен має право на підприємницьку діяльність, яка не заборонена законом. Держава також забезпечує захист конкуренції у підприємницькій діяльності.

Як показує досвід розвинених країн, підприємництво $є$ основою для макроекономічної стабільності держави, а саме збалансованість економічної системи $€$ ключовою для стабільності а також постійно існують дестабілізовані фактори, які постійно впливають на економічну стабільність (Korobets, O.M., Slavkova O.P., ShynkarenkoM.M., 2018).

Аналіз останніх досліджень і публікацій. Дослідження інституційних засад розвитку підприємництва питання інноваційне та знаходиться в полі зору дослідників. Проблеми інституційного забезпечення підприємництва в агарній сфері розкриваються у наукових працях таких вчених як: Дриманова Л.М. (Дриманова Л.М., 2015), Korobets, O.M. (Korobets, O.M. Slavkova O.P., Shynkarenko M.M., 2018), Корогод І. В. (Корогод І. В., 2015), Осадчук С. В. (Осадчук С. В., 2018), Петруня Ю.Є. (Петруня Ю.Є., Івашина О.Ф., 2010), Склярець Д. В. (Склярець Д. В., 2013), Усюк Т.В. (Усюк Т.В., 2014), Шпикуляк О.Г. (Шпикуляк О.Г., Малік М.Й., 2019) та інших. Цінність досліджень вищеназваних авторів полягає в визначенні інституційних засад але деякі аспекти залишаються невизначеними, особливо в умовах постійних змін в політичній та соціально-економічній ситуації в країні.

Формулювання цілей статті. Метою даного дослідження $€$ аналіз ситуації з формуванням підприємництва, розгляд системи та пошук шляхів покращення інституційного середовища в аграрній сфері.

Методи дослідження. У дослідженні було використано такі методи як: метод аналізу, метод порівняння, емпіричний метод наукового дослідження та метод логічного узагальнення. За їх допомогою було визначено основні тенденції розвитку підприємництва в Україні, прогнозні показники та очікування сільськогосподарських виробників від ведення бізнесу та визначення шляхів покращення інституційного середовища.

Виклад основного матеріалу дослідження. Підприємництво в Україні характеризується як кількісними так і якісними характеристиками, які представлені в нижче приведених таблицях. Аналізуючи таблицю 1 стосовно частки суб'єктів великого, середнього, малого та мікропідприємництва у загальній кількості суб'єктів господарювання за видами економічної діяльності в сільському, лісовому та рибному господарстві відносно до загальної кількості підприємств можна зробити наступні висновки. Перше частка суб'єктів господарювання за їх розмірами у загальній кількості суб'єктів господарювання у відсотках суб'єктів великого підприємництва складає 0,00 відсотків, що свідчить про те, що в аграрному виробництві доля великого бізнесу дуже мала. Друге - суб'єкти середнього підприємництва складають в 2018 році 3,1 відсотка, в порівнянні з 2010, коли цей показник дорівнював 4,3 відсотка.

Третє - суб'єкти малого підприємництва у відсотках до загальної кількості суб'єктів господарювання складають у 2018 році 96,9 відсотків, що на 1,2 більше ніж в 2010 році, причому з них приблизно 90,0 відсотків мікропідприємств. До суб'єктів мікропідприємництв відповідно до ст. 55 Господарського кодексу України відносять юридичні особи суб'єкти господарювання будь-якої організаційно-правової форми та форми власності, у яких середня кількість працівників за звітний період (календарний рік) не перевищує 10 осіб та річний дохід від будь-якої діяльності не перевищує

Вісник Сумського національного аграрного університету

Серія «Економіка і менеджмент», випуск 2 (80), 2019 
суму, еквівалентну 2 мільйонам євро, визначену за середньорічним курсом НБУ.

Таблиця 1

1. Частка суб'єктів великого, середнього, малого та мікропідприємництва у загальній кількості суб'єктів господарювання за видами економічної діяльності в сільському, лісовому та рибному господарстві

\begin{tabular}{|c|c|c|c|c|c|}
\hline \multirow[b]{2}{*}{ Роки } & \multirow{2}{*}{$\begin{array}{l}\text { Кількість суб'єктів } \\
\text { господарювання } \\
\text { - усього, одиниць }\end{array}$} & \multicolumn{4}{|c|}{ Частка суб'єктів господарювання за їх розмірами у загальній кількості суб'єктів господарювання, у \% } \\
\hline & & $\begin{array}{l}\text { суб'єкти великого } \\
\text { підприємництва }\end{array}$ & $\begin{array}{c}\text { суб'єкти середнього } \\
\text { підприємництва }\end{array}$ & $\begin{array}{l}\text { суб'єкти малого } \\
\text { підприємництва }\end{array}$ & $\begin{array}{c}\text { 3 них суб'єкти } \\
\text { мікропідприємництва }\end{array}$ \\
\hline 2010 & 80321 & 0,0 & 4,3 & 95,7 & 90,2 \\
\hline 2011 & 61488 & 0,0 & 5,3 & 94,7 & 85,6 \\
\hline 2012 & 68497 & 0,0 & 4,6 & 95,4 & 87,1 \\
\hline 2013 & 71058 & 0,0 & 4,1 & 95,9 & 87,8 \\
\hline 2014 & 75660 & 0,0 & 3,8 & 96,2 & 87,6 \\
\hline 2015 & 79284 & 0,0 & 3,2 & 96,8 & 90,4 \\
\hline 2016 & 74620 & 0,0 & 3,4 & 96,6 & 89,7 \\
\hline 2017 & 76593 & 0,0 & 3,1 & 96,9 & 89,9 \\
\hline
\end{tabular}

Джерело: (Діяльність суб'єктів великого, середнього, малого та мікропідприємництва за 2017 рік, 2018)

Таким чином в сільському господарстві переважають невеликі мікропідприємства, які й складають основну масу. Важливим для аналізу є визначення питомої ваги фізичних осіб підприємців у загальній кількості суб'єктів великого та середнього підприємництва (таблиця 2).

В кількісному складі на початок 2018 року в порівнянні до 2010 роком суб'єктів великого підприємництва збільшилося на 38,5 відсотків.На обліку не враховуються фрізичні особи підприємці в зв'язку з тим, що така форма підприємницької діяльності не може бути зареєстрована як велике підприємство. Інша ситуація з середніми підприємствами, для цієї групи ситуація навпаки іншою динамікою.Так в 2017 році їх кількість складала 2383 одиниці, тоді як в 2010 році на обліку налічувалося 3440 одиниць, що на 30,1 відсотка менше ніж в 2017 році.

2. Кількість підприємств та фрізичних осіб-підприємців за їх розмірами за видами економічної діяльності

Таблиця 2 в сільському, лісовому та рибному господарстві

\begin{tabular}{|c|c|c|c|c|c|c|}
\hline \multirow{3}{*}{ Роки } & \multicolumn{3}{|c|}{ Суб'єкти великого підприємництва } & \multicolumn{3}{|c|}{ Суб'єкти середнього підприємництва } \\
\hline & \multirow{2}{*}{ усього } & \multicolumn{2}{|c|}{ у тому числі } & \multirow{2}{*}{ усього } & \multicolumn{2}{|c|}{ у тому числі } \\
\hline & & підприємства & фізичні особи підприємці & & підприємства & фізичні особи підприємці \\
\hline 2010 & 13 & 13 & - & 3445 & 3440 & 5 \\
\hline 2011 & 16 & 16 & - & 3282 & 3274 & 7 \\
\hline 2012 & 26 & 26 & - & 3158 & 3143 & 15 \\
\hline 2013 & 27 & 27 & - & 2926 & 2915 & 11 \\
\hline 2014 & 28 & 28 & - & 2876 & 2595 & 281 \\
\hline 2015 & 29 & 29 & - & 2535 & 2533 & 2 \\
\hline 2016 & 20 & 20 & - & 2505 & 2501 & 4 \\
\hline 2017 & 18 & 18 & - & 2391 & 2383 & 8 \\
\hline
\end{tabular}

Джерело: (Діяльність суб'єктів великого, середнього, малого та мікропідприємництва за 2017 рік, 2018)

Але парадоксально виглядає ситуація 2014 року, коли на обліку було 281 підприємство а в наступному році залишилося лише дві одиниці.

Збільшення кількості середніх та малих підприємств можна передбачати через пріоритетний розвиток фермерських господарств та сільськогосподарської кооперації шляхом удосконалення державної аграрної політики, інституційного середовища, організаційно-економічного механізму, фінансового та інформаційного забезпечення фермерських господарств відповідно до Концепції розвитку фермерських господарств та сільськогосподарської кооперації на 2018-2020 роки (Концепція розвитку фермерських господарств та сільськогосподарської кооперації на 2018-2020 роки, 2017), що приведе до сталого економічного зростання, покращення соціальної ситуації у сільській місцевості.

Підприємницька діяльність в сільському господарстві пов'язана з постійними ризиками. Одним з яких, наприклад, $є$ посилення гібридних загроз національній економіці з боку Російської Федерації, яке може призвести до повної блокади портів Азовського моря. Така ситуація може також позначиться на діяльності окремих видів переробної промисло- вості (металургії та будівельних матеріалів) та непрямих витрат,що можуть понести виробники сільськогосподарської продукції, що пов'язано з розрахунками нових логістичних маршрутів (Прогноз економічного і соціального розвитку України на 2020-2022 роки. Постанова Кабінету Міністрів України №555 віл 15.05.2019 р., 2019).

Ще одним ризиком є отримання низького врожаю зернових культур пов'язана з специфрічною особливістю аграрної галузі, що можуть призвести до зменшення обсягів врожаю сільськогосподарських культур вплине на розвиток сільського господарства в цілому та відповідно ВВП, скорочення експортних можливостей аграрних виробників, прискорить інфляційні процеси в Україні.

Найбільш державної та інституційної підтримки потребує галузь тваринництва. Як ми можемо бачити з таблиці по вибраним напрямкам виробництва велика рогата худоба $27 \%$ вирощується на невеликих фермах до 50 голів, тобто це ті виробники, які потребують допомоги та впливу держави в свою діяльність. Щодо вирощування свиней ситуація дуже схожа, де 22,1\% вирощуються на підприємствах до 100 голів.

Що стосується свійської птиці, то можна сказати, що найбільше підприємств $(41,6 \%)$ вирощують птицю на фермах 
до 4999 голів, але це складає тільки 0,2\% кількості голів, що свідчить про ймовірну потребу даних підприємств в державній допомозі. Також ситуація спостерігається з вирощування овець, кіз та корів.
Щодо очікування зміни обсягу виробництва продукції сільського господарства в наступні три місяці, то в третьому кварталі 2019 року, як і в третьому кварталі 2015 року підприємці очікують збільшення виробництва (таблиця 3).

Таблиця 3

3. Оцінка змін обсягу виробництва продукції сільського господарства за попередні три місяці (відсотків до загальної кількості опитаних підприємств)

\begin{tabular}{|c|c|c|c|c|c|c|c|c|c|c|}
\hline & \multicolumn{5}{|c|}{ III квартал 2015p. } & \multicolumn{5}{|c|}{ III квартал 2019 р. } \\
\hline & збільшиться & $\begin{array}{c}\text { не } \\
\text { зміниться }\end{array}$ & зменшиться & $\begin{array}{c}\text { немає } \\
\text { відповіді }\end{array}$ & баланс & збільшиться & $\begin{array}{c}\text { не } \\
\text { зміниться }\end{array}$ & зменшиться & $\begin{array}{c}\text { немає } \\
\text { відповіді }\end{array}$ & баланс \\
\hline $\begin{array}{l}\text { Сільське } \\
\text { господарство* }^{*}\end{array}$ & 27 & 53 & 18 & 2 & 9 & -19 & 38 & 46 & 16 & 0 \\
\hline Рослинництво & 27 & 54 & 19 & 0 & 8 & -25 & 41 & 43 & 16 & 0 \\
\hline Тваринництво & 28 & 53 & 19 & 0 & 9 & -6 & 32 & 50 & 18 & 0 \\
\hline
\end{tabular}

* Без урахування тимчасово окупованої території Автономної Республіки Крим, м. Севастополя та частини тимчасово окупованих територій у Донецькій та Луганській областях.

Джерело: (Очікування сільськогосподарських підприємств щодо перспектив розвитку їх ділової активності за видами економічної діяльності (2015-2019), 2019).

Половина, а саме $52 \%$ з них сподівається на баланс в своєму підприємстві, хоча в 2015 році таких підприємців було - 61\%, причому з них 70\% ті які працюють в галузі рослинництва, а $47 \%$ в галузі тваринництва.
3 боку держави важливим показником розвитку любої галузі є зменшення безробіття (таблиця 4).

Очікувані зміни кількості працівників на сільськогосподарських підприємствах у наступні три місяці (відсотків до загальної кількості опитаних підприємств)

\begin{tabular}{|c|c|c|c|c|c|c|c|c|c|c|}
\hline & \multicolumn{5}{|c|}{ III квартал 2015p. } & \multicolumn{5}{|c|}{ III квартал 2019 р. } \\
\hline & збільшиться & $\begin{array}{c}\text { He } \\
\text { зміниться }\end{array}$ & зменшиться & $\begin{array}{c}\text { немає } \\
\text { відповіді }\end{array}$ & баланс & збільшиться & $\begin{array}{c}\text { не } \\
\text { зміниться }\end{array}$ & зменшиться & $\begin{array}{c}\text { немає } \\
\text { відповіді }\end{array}$ & баланс \\
\hline Сільське господарство* & 22 & 71 & 7 & 0 & 15 & 19 & 74 & 7 & 0 & 12 \\
\hline Рослинництво & 27 & 66 & 7 & 0 & 20 & 21 & 72 & 6 & 1 & 15 \\
\hline Тваринництво & 13 & 80 & 6 & 1 & 7 & 13 & 78 & 8 & 1 & 5 \\
\hline
\end{tabular}

* Без урахування тимчасово окупованої території Автономної Республіки Крим, м. Севастополя та частини тимчасово окупованих територій у Донецькій та Луганській областях.

Джерело: (Очікування сільськогосподарських підприємств щодо перспектив розвитку їх ділової активності за видами економічної діяльності (2015-2019), 2019).

Сільське господарство вирізняється сезонністю виробництва, тому важливим є питання очікування змін в кількості працівників. Дані показують, що більшість 74\% від загальної кількості опитаних підприємств вважають, що кількість робітників не зміниться, позитивним є те що 19\% вважають, що вона збільшиться проти 7\%, які вважають що вона зменшиться, при цьому збільшення прогнозують в напрямку розвитку рослинництва.

В роботі сільськогосподарських підприємств існує багато чинників, які стримують роботу. Анкетування свідчить, що якщо порівняти данні 2019 року з даними 2015 року, то в цей же період найбільшими стримуючими факторами були фінансові обмеження в 2015 році - 51\% та меншими були оптимістичні підприємці щодо того, що їх нічого не стримує (таблиця 5).

Таблиця 5

Оцінка впливу факторів, що стримують сільськогосподарську діяльність

\begin{tabular}{|c|c|c|c|c|c|c|c|c|c|c|c|c|c|c|}
\hline & \multicolumn{7}{|c|}{ III квартал 2015p. } & \multicolumn{7}{|c|}{ III квартал 2019 р. } \\
\hline & 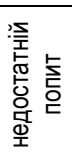 & $\begin{array}{l}\text { 墒 } \\
\text { 产 } \\
\text { 言 } \\
\text { 응 }\end{array}$ & 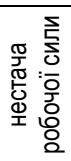 & 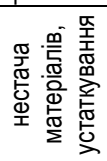 & 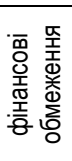 & 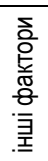 & 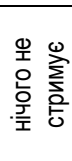 & 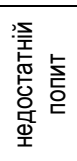 & 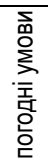 & 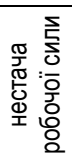 & 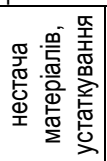 & 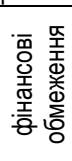 & 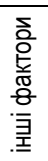 & 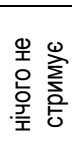 \\
\hline $\begin{array}{l}\text { Сільське } \\
\text { господарство* }\end{array}$ & 11 & 23 & 1 & 8 & 51 & 26 & 20 & 10 & 28 & 4 & 2 & 22 & 21 & 38 \\
\hline Рослинництво & 9 & 26 & 1 & 8 & 47 & 24 & 21 & 7 & 32 & 3 & 1 & 19 & 20 & 41 \\
\hline Тваринництво & 12 & 16 & 2 & 8 & 54 & 26 & 17 & 17 & 18 & 6 & 3 & 28 & 25 & 32 \\
\hline
\end{tabular}

* Без урахування тимчасово окупованої території Автономної Республіки Крим, м. Севастополя та частини тимчасово окупованих територій у Донецькій та Луганській областях. (2015-2019), 2019)

В розрізі рослинництва та тваринництва можна констатувати той фракт, що виробництво продукції рослинництва з точки зору підприємців має менші перешкоди ніж виробництво продукції тваринництва, починаючи з таких основних як недостатній попит 17\% та фінансові обмеження
$23 \%$.

Відповідно до даних опитування в 2019 році підприємці серед основних фракторів, що стримують сільськогосподарську діяльність виділяють наступні: недостатній попит на продукцію сільського господарства - 
$10 \%$, погодні умови - 28\%, нестача робочої сили - $4 \%$, нестача матеріалів та устаткування - $2 \%$, фінансові обмеження - 22\%, інші фрактори - 21\%. Ціновим $€$ те, що практично більше третини підприємців, а саме $38 \%$ вважають, що в роботі їх нічого не стримує.

Документами які регламентують діяльність підприємств та створюють інституційне середовище $є$ наступні: Господарський кодекс (Господарський кодекс України, 200)], Цивільний кодекс (Цивільний кодекс України, 2013) та Податковий кодекс України (Податковий кодекс України, 2010). В ссрері малого підприємництва в аграрній ссрері таким нормативним єЗакон України «Про розвиток та державну підтримку малого і середнього підприємництва в Україні» (Про розвиток та державну підтримку малого і середнього підприємництва в Україні, 2012) визначено правові та економічні засади державної політики у сфері підтримки та розвитку малого і середнього підприємництва.

Результатів досліджень багатьох авторів свідчать про важливість інституційного середовища для розвитку підприємництва та на думку деяких з них воно суттєво впливає на конкурентоспроможність суб'єктів господарювання, позначається на інвестиційних рішеннях та організації виробництва, а також впливає на економічне зростання (Корогод I. В., 2015). Таке середовище визначається правовою й адміністративною інфраструктурою, у межах якої приватні підприємці, компанії і уряд взаємодіють з метою створення добробуту нації (Звіт про конкурентоспроможність регіонів, 2013, с. 13). В широкому розумінні на думку Склярець Д. В.інституційне середовище - це сукупність інститутів та інституцій (Склярець Д. В., 2013, с. 25). А під інститутом розуміється Петруня Ю.Є. розуміє історично сфрормовані норми і правила суспільної поведінки, які виражаються через набір законів, нормативів, обмежень, які є обов'язковими для виконання (формальний рівень), або через набір моральних установок, принципів суспільної поведінки, традицій тощо (неформальний рівень) (Петруня Ю.Є., Івашина О.Ф., 2010, с. 44).

Інституції можна поділити на державні та приватні та на нашу думку їх значення однаково важливе для розвитку підприємництва в агарній сфері.

В цілому інституційне середовище регулювання розвитку підприємництва в аграрній сфері в Україні складається 3:

1. Президента України, який має право законодавчої ініціативи, в тому числі стосовно питань розвитку підприємництва в аграрній ссрері.

2. Верховної Ради України, яка має право законодавчої ініціативи, в тому числі стосовно питань розвитку підприємництва в аграрній сфрері.

3. Кабінету Міністрів України, вищого органу у системі органів виконавчої влади, що забезпечує здійснення внутрішньої політики держави; щодо розвитку підприємництва в агарній сфрері.

4. Комітету Верховної Ради України з питань аграрної та земельної політики, який здійснює законопроектну роботу, готує, попередньо розглядає питання, віднесені до повноважень Верховної Ради України, та виконує контрольні функції, зокрема, у сфрері економічної політики в агропромисловому комплексі, державного регулювання агропромислового виробництва та прикладних наукових досліджень в аграрній сфрері, сільськогосподарської кооперації, регулювання зе- мельних відносин (крім земельних відносин у межах територій забудови), лісового, водного та рибного господарства.

5. КомітетКомітету Верховної Ради України з питань 3 питань економічного розвитку: який здійснює законопроектну роботу, готує, попередньо розглядає питання, віднесені до повноважень Верховної Ради України з розвитку підприємницької діяльності та гарантування прав і законних інтересів суб'єктів підприємницької діяльності.

6. Комітет з питань фрінансів, податкової та митної політикиякий здійснює законопроектну роботу, готує, попередньо розглядає питання, віднесені до повноважень Верховної Ради України з системи оподаткування, загальнодержавних податків і зборів (мита, плата, інші обов'язкові платежі), місцевих податків та зборів, інших доходів бюджету неподаткового характеру, єдиного соціального внеску на загальнообов'язкове державне соціальне страхування, а також інших нарахувань на фонд оплати праці.

7. Міністерство розвитку економіки, торгівлі та сільського господарства $€$ головним органом у системі центральних органів виконавчої влади, що забезпечує формування та реалізацію політики у сфері підприємництва.

8. Інші центральні органи виконавчої влади, які в межах повноважень прямо чи опосередковано впливають на розвиток підприємництва в аграрній сфері, а саме: Міністерство фінансів України, Міністерство освіти і науки України, Міністерство соціальної політики, Міністерство регіонального розвитку, будівництва та житлово-комунального господарства України, Міністерство юстиції України, Державна регуляторна служба України та інші.

9. Ради підприємців при Кабінеті Міністрів України постійно діючий консультативно-дорадчий орган; готує пропозиції щодо створення правових, економічних та організаційних умов для подальшого розвитку підприємницької діяльності; місцевих державних адміністрацій - забезпечують виконання державних і регіональних програм соціально-економічного розвитку, у тому числі програм розвитку малого та середнього підприємництва, які фінансуються за рахунок місцевих бюджетів або інших не заборонених законодавством джерел; інфраструктури підтримки малого підприємництва.

10. Торгово-промислова палата України та регіональні торгово-промислові палати.

11. Громадські організації підприємців та роботодавців, наукові установи, консультаційно-дорадчі органи при органах державної влади та органах місцевого самоврядування.

12. Іноземні донори, які надають трансфер інноваціям, технічну, освітню підтримку підприємництва в агарній copepi.

Виходячи з вище переліченого інституційне забезпечення розвитку підприємництва в аграрній сфері $є$ достатньо досить міцним, але має свої недоліки а саме розпорошення по міністерствам, окремим елементам системи державного управління. Це призводить до розпорошення уваги стосовно цього питання, особливо як наголошує Осадчук С.В. (Осадчук С. В., 2018) результативність великої кількості інституцій не приводить до позитивних результатів в підтримці малого підприємництва.

Такої ж думки притримується Усюк Т.В. (Усюк Т.В., 2014) яка в своїх дослідження доводить, що ефективність ро- 
звитку сільського підприємництва знаходиться у нерозривному зв'язку з можливістю управлінської системи підприємств вчасно реагувати та впроваджувати зміни інституційного характеру. Автором сорормовано алгоритм процесу імплементації інституційних змін у діяльність суб'єктів сільського підприємництва, яким визначено п'ять послідових етапів: 1) отримання інформації про зміну формальних інституцій; 2) формування цінової політики на ресурси та продукцію; 3) специфікація прав власності; 4) зміна пріоритетів у виборі інституцій щодо управління підприємницьким формуванням (адаптація системи управління або її неузгодженість у відношенні до змін); 5) оптимізація рівня трансакційних витрат (Усюк Т.В., 2014, с. 12].

Основними формами державної підтримки підприємництва в агарній сфері є: політична, економічна, соціальна, екологічна. Основне місце посідає економічна та політична підтримка, яка означає підтримку інтересів сільськогосподарських виробників, які відповідають основним напрямкам аграрної політики держави та її національним інтересам. Але підприємництво в аграрній сфері також пов'язане з розв'язанням соціальних проблем в сільській місцевості, а саме необхідністю участі держави у розв'язанні соціальних проблем села, розбудовою ринку праці, екологічних проблем та інше.

Але як пише Л.М. Дриманова непрозорий та нерівномірний розподіл державної допомоги надається обмеженому колу привілейованих виробників та спостерігаються регулярні скарги від бізнесу (щодо непрозорого розподілу державної підтримки) (Дриманова Л.М., 2015).

Відповідно до прогнозу економічного і соціального розвитку України на 2020-2022 роки для неї зростатиме значення держав АCEAH, як потенційно важливих партнерів. Серед чинників, що підвищуватимуть важливість азійського напряму для України та спонукатимуть до диверсифікації зовнішньоекономічної політики, будуть: часткова втрата ринку Російської Федерації, високий імпортний потенціал регіону, можливість участі в реконструкції та модернізації діючих енергетичних об'єктів та житлового будівництва, а також промислових об'єктів та комунікацій а також можливість залучення фінансів великих регіональних держав-інвесторів (Малайзія, Сінгапур, Таїланд) у сільське господарство, сировинні сектори, сферу транспорту та реалізацію інфрраструктурних проектів.(Прогноз економічного і соціального розвитку України на 2020-2022 роки., 2019, с.24)

На нашу думку в контексті пріоритетного розвитку малого і середнього підприємництва у сфері сільськогосподарського виробництва можна розраховувати при спрощенні адміністрування податків та створення умов для покращення доступу до кредитних ресурсів. Важливим також є зменшення монополізації ринків сільськогосподарської продукції та матеріально-технічних ресурсів.

Висновки Виходячи 3 вищезазначеного ми вважаємо, що підтримка розвитку підприємництва повинна базуватися на сприятливому інституційному середовищі. Сьогодні в Україні існують окремі невирішені проблеми, які стримують підприємницьку діяльність.

На нашу думку удосконалення нормативної бази та реорганізація органів управління призведе до покращення інституційного середовища, що в свою чергу стане потужним інструментом для активізації підприємницької діяльності та сталому економічному розвитку держави.Подальші свої дослідження з даного питання ми вбачаємо в розробці дієвих механізмів створення сприятливих умов для розвитку підприємництва в агарній сфері як з боку держави так і збоку іноземних донорів в частині технічної, інформаційної та навчальної підтримки.

\section{Список літератури:}

1. Constitution of Ukraine: Law of June 28, 1996 No. 254k / 96-BP. Availableat: https://zakon.rada.gov.ua/laws/show/254\%D0\%BA/96-\%D0\% B2\% D1\% 80. (Accessed 01.09.2019).

2. Korobets, O.M., Slavkova O.P., Shynkarenko M.M. (2018) Analysis of the Macroeconomic Stability Indicators Changing Dynamics in Ukraine. The mechanism of regulation of the economy. № 4. C. 127-134.

3. Drymanova LM (2015) Institutional foundations for reforming state support for agrarian entrepreneurship. Economics, finance, management: Topical issues of science and practice. №3. P.31-39.

4. Korogod I.V. (2015) Institutional principles of activation of entrepreneurial activity in the conditions of decentralization of powers. An efficient economy. No. 11. Availableat: file: /// C: /Users/1/Downloads/efek_2015_11_108.pdf. (Accessed 09/01/2019).

5. Osadchuk SV (2018) Institutional and regulatory principles of small business activity. Aspects of Public Management. Volume 6. No. 8. P. 71-77. Availableat: file: I// C: /Users/1/Downloads/438-Article\%20Text-594-1-10-20180913.pdf. (Accessed 09/01/2019).

6. Petrunya Yu. E., Ivashina OF (2010) Institutional Factors for Economic Development. Economic theory. 2010. № 4. P. 2431.

7. Sklyarets D.V. (2013) Directions for improvement of the institutional environment of formation and functioning of regional food markets. Economy. Management. Entrepreneur ship. No. 25 (1). Pp. $42-53$.

8. Vseuk TV (2014) Institutional principles of rural entrepreneurship development. Thesis for Candidate of Economic Sciences, specialty 08.00.04 - Economics and Management of Enterprises (by types of economic activity). 21s.

9. Shpikuliak OG, Malik M.Y. (2019) Institutional analysis of entrepreneurship development in the agrarian sector of the economy: a methodological aspect. APK economy. No. 6. P.73-82.

10. Shpikuliak OG, Malik M.Y. (2019) Development of institutional forms of economic activity in rural areas. Seventeenth Cong. scientist. agrarian economists and the International Scientific and Practical Conference, Kyiv, May 30. 2019, P.275-280.

11. Activities of large, medium, small and micro-entities in 2017. State Statistics Service. 2018. 334 p. Availableat: https://ukrstat.org/uk/druk/ publicat/ kat_u/2018/zb/11/zb_dsp_2017.pdf. (Accessed 09/01/2019).

12. The concept of farm development and agricultural cooperation for 2018-2020. Availableat: https://www.kmu.gov.ua/storage/app/media/ reforms/ kontseptsiya-rozvitku-fermerskikh-gospodarstv-i-silskogospodarskoi-kooperatsii-na-2018-2020-roki.pdf. (Accessed 09/01/2019). 
13. Forecast of economic and social development of Ukraine for 2020-2022. Resolution of the Cabinet of Ministers of Ukraine No. 555 Villas 15.05.2019 Availableat: https://www.kmu.gov.ua/en/npas/pro-shvalennya-prognozu-ekonomichnogo-i-socialnogorozvitku-ukrayini-na-20202022-roki-i150519. (Accessed 09/01/2019).

14. Expectations of agricultural enterprises on the prospects of development of the in business activity by types of economic activity (2015-2019). Availableat: https://ukrstat.org/uk/operative/menu/menu_u/tda.htm. (Accessed 09/01/2019).

15. Commercial Code of Ukraine dated January 16, 2003, No. 436-IV. Availableat: http://zakon.rada.gov.ua/laws/ show / 43615. (Accessed 09/01/2019).

16. The Civil Code of Ukraine. No. 435-IV, January 16, 2003. Availableat: https://zakon.rada.gov.ua/laws/show/435-15. (Accessed 09/01/2019).

17. Tax Code of Ukraine of December 2, 2010 № 2755-VI. Availableat: https://zakon.rada.gov.ua/laws/show/2755-17. (Accessed 09/01/2019).

18. About development and state support of small and mediumbusinessin Ukraine. Law of Ukraine No. 4618-VI of March 22, 2012 Availableat: https://zakon.rada.gov.ua/laws/show/4618-17. (Accessed 09/01/2019).

19. Regional Competitiveness Report (2013). K.: Foundation for Effective Governance, 2013. 340 p.

Andrii Sukhostavets, PhD, Associate Professor, Sumy National Agrarian University (Sumy, Ukraine)

Institutional basis for the development of enterprises in the agrarian sphere

The situation with the formation of entrepreneurship, its institutional environment was analyzed in the article; the ways to improve the institutional environment for the development of entrepreneurship in the agricultural sector were developed.

According to the results of the study, it was firstly determined that the share of economic entities by their size in the total number of economic entities as a percentage of large enterprises is 0.00 percent, which indicates that the share of large businesses in agricultural production is very small. Secondly, medium-sized businesses accounted for 3.1 percent in 2018, compared to 4.3 percent in 2010. Thirdly, small businesses account for 96.9 percent of total business entities in 2018, which is 1.2 more than in 2010, of which approximately 90.0 percent are microenterprises.

Studies have shown that according to the 2019 survey, among the main factors restraining agricultural activity, entrepreneurs identified the following: insufficient demand for agricultural products - $10 \%$, weather conditions - $28 \%$, labor shortage - $4 \%$, lack of materials and equipment - $2 \%$, financial restrictions - $22 \%$, other factors - $21 \%$. It is important to note that almost more than a third of entrepreneurs, namely $38 \%$ believe that nothing is holding them back in their work.

The article defines that the main forms of state support of entrepreneurship in the agrarian sphere are: political, economic, social, environmental. Emphasis is placed on economic and political support, which means supporting the interests of agricultural producers, who are in line with the main directions of the state's agricultural policy and its national interests. The simplification of tax administration and the creation of conditions for improving access to credit resources were identified as factors that facilitate the entrepreneurship development. It is also important to reduce the monopolization of agricultural markets and material and technical resources.

The article proves that support for entrepreneurship development should be based on a favorable institutional environment; it is determined that the stimulating factor for the development of entrepreneurial activity is the improvement of the regulatory framework and reorganization of governing bodies, which will lead to an improvement in the institutional environment and, in turn, will become a powerful tool for enhancing entrepreneurial activity and will contribute to sustainable economic development of the state.

We have determined that in the future, the research on this issue will be aimed at the development of effective mechanisms for creating favorable conditions for the development of entrepreneurship in the agrarian sector, both from the state and foreign donors in terms of technical, information and educational support.

Keywords: entrepreneurship production of cereals, grain market, grain farming, coarse grains, cultivation.

Дата надходження до редакції: 02.02.2019 р. 